\title{
Formation of Iranian Studies at the Kazan University (19th-Early 20th Centuries)
}

\author{
Ramil M. Valeev ${ }^{1}$, Roza Z. Valeeva ${ }^{1}$, Timur I. Zyapparov ${ }^{1} \&$ Emil R. Valeev $^{1}$ \\ ${ }^{1}$ Kazan (Volga Region) Federal University, Kazan, Russia \\ Correspondence: Ramil M. Valeev, Kazan (Volga Region) Federal University, 420008, Kazan, Kremlyovskaya \\ Street 18, Russia. E-mail: valeev200655@mail.ru; ram.valeev2016@yandex.ru
}

Received: June 2, 2015 Accepted: June 15, 2015 Online Published: June 29, 2015

doi:10.5539/jsd.v8n5p149 URL: http://dx.doi.org/10.5539/jsd.v8n5p149

\begin{abstract}
The article involves the historical and scientific study of the Iranian Cultural Heritage in Russia in the 19th century. It presents the background of the Persian language and literature teaching at Russian universities. Initiators and the ways the Iranian Studies developed at the Kazan University are mentioned. The historical events dealing with political and cultural relations of the peoples of the Volga-Ural region and Iran are summarized. It focuses on a variety of materials, covering the events, the heritage of Orientalists and Iranian scholars and results in the formation of Iranian Studies at the Kazan University in the 19th century. This research will provide valuable information regarding scientific and educational activities of Orientalists of the University, associated with teaching the Persian language, linguistic, literary, historical, ethnographic studies of the history and culture of Iran.
\end{abstract}

Keywords: Iran, Persian cultural heritage, Oriental Studies, Centers of Oriental Studies in Russia, Oriental and Iranian Studies at Kazan University, The Iranian Studies, Orientalists

\section{Introduction}

The scientific study of the Iranian political, cultural and ethno-linguistic field, which includes Iran, Afghanistan, also republics of Central Asia and parts of India, has a long and important tradition in Russia and Europe. Iranian political and cultural heritage played an important role in the history and culture of the peoples of the Russian Commonwealth.

Classical Iranian Studies in Russia formed and developed throughout 19th and early 20th centuries. It is an actual scientific discipline of Oriental studies. The origins of practical and scientific Iranian Studies in Russia are related to the comprehensive study of the Arab-Muslim East. The study of Iranian languages, the monuments of Persian classical literature and the culture of the Iranian civilization became the basis of classical Iranian Studies of academic and university centers in Russia.

The starting point for teaching the Persian language in Russia was 1807 (the Kazan Imperial University). In 1811 this language appeared in the curriculum of Moscow University. Since 1819 Persian was taught by F.B. Sharmua (1793 - 1868) and M.D. Topchibashev (1790 - 1869) at St. Petersburg University. Since 1829 B.A. Dorn (1805 1881) ran Persian literature course at Kharkov University.Russian Iranian Studies provide with a variety of data dealing with archeology, epigraphy, history, culture, religion, philosophy, pre-and Islamic literature and poetry of the Iranian peoples. (History of Russian Oriental Studies to middle of the 19th century, (1990), History of Russian Oriental Studies from the middle of the 19th century to 1917 (Valeev, 1998; Andreeva, 2007; Hodkinson et al., 2013; From the history of Kazan Iranian Studies, 2013).

On the whole the 19th century is characterized by the development of higher education and scientific cultural and historical foundations of the study of pre-Islamic and Islamic Iranian civilization in the history of the Russian and European Oriental Studies. Important components of the early stage of educational and scientific study of the history and culture of the peoples of Iran in Russia in the 18th and 19th centuries are: translated and authentic materials with a variety of Iranian subjects; original research work in the field of Iranian Linguistics; publications of linguistic materials - texts, poems and vocabulary in various Iranian languages; understanding of a variety of materials of Greek authors in the history and culture of ancient Iran (Herodotus, Xenophon); study of European achievements of decipherment of ancient Persian cuneiform inscriptions (G. Grotefend, Chr. Lassen, E. 
Burnouf, Mr. Rawlinson); critical interpretation of published ancient sacred texts of the Zoroastrian religion (A. Duperron, E. Burnouf), and systematization of the main problems of the history of ancient and modern Iran (Greco-Persian Wars, 500-449 BC., political and diplomatic history, economics, social institutions, culture of Persian state and society).

Formation and development of Kazan Russian scientific school of Iranian Studies (19th - beg. 20th century) testifies to the complex study of historical-philological and historical-comparative research.

\section{Methodological Framework}

The methods of this study are based on a variety of modern principles and ideas - philosophical, epistemological and logical, which play an important role in the study of events, milestones and directions of the formation of Russian Iranian studies, including the Kazan University's Center of Iranian Studies.

The main method is comparative historical research. It allows to spotlight the formation and development of the Iranian Studies in Russia and Europe, in close connection with the historical factors, as well as the social and political situation in Russia in the 19th - early 20th centuries.

The next method of research is periodization of Russian Oriental history, including the history of Kazan Center of Iranian Studies. The historical periodization of the Kazan University Iranian Studies of the 19th - beg. 20th centuries is based on objective and subjective criteria highlighting the institutional forms of Oriental Studies, including Iranian Studies in Russia and Europe, research methods and the nature of teaching and research activities of Russian Orientalists, etc. The choice of the method comes out of the fixed time frame of the process of formation and development of Iranian studies in Kazan.

The method of the system approach allows us to consider the main components of the research, Iranian Studies at the University, the historical and scientific events devoted to the study of history and culture of the people of Iran in the activities of societies and associations, scientific work of Orientalists, etc., and their interactions.

Chronological and problematic chronological methods allow to examine the formation of Iranian education in Kazan in consistency and coherence. This method of studying the history of the formation of Iranian Studies at the University, the preparation and publication of textbooks and curricula, teaching Arab-Muslim languages at the first Kazan gymnasium and the university is important not only for the history of Oriental Studies in Kazan, but also it allows to evaluate Oriental Studies in the 19th century in Russia and the world.

On the whole, the various methods of the research allow to highlight the development of Iranian Studies at the Kazan University, its general, special and rare phenomena and facts. There are traditional characteristics of the development of Iranian Studies at the Kazan University in 19 th and 20 th centuries typical for the Centers of Oriental Studies in Russia and Europe along with some unique and special ones.

\section{Results}

A variety of materials and especially archival documents indicate that Iranian studies were an integral part of the Kazan Oriental studies of the 19th century. Historical ties between the peoples of the Volga region and the regions of Iranian culture played a significant role in the development of Iranian Studies at the Kazan University.

History of political, commercial and cultural contacts between the ancestors of the Volga-Ural region and Persia goes back to centuries.

Formation of Khazar state in the Lower Volga and Fore-Caucasus (middle of the 7th century) and the state of Volga Bulgaria in the Middle Volga (10th century) contributed to the establishment of permanent contacts between the Volga and the traditional regions with Iranian culture spread, Central Asia, Iran and Afghanistan. A major role in the development of these ties played functioning of the Great Volga trade route linking the Middle East with Eastern and Northern Europe. Cultural ties between the Volga and the Iranian-speaking countries especially intensified after the adoption of the Volga Bulgar Islam as the state religion (year - 922). Students and scholars of the Volga Bulgaria trained and worked in recognized centers of Iranian-Islamic culture - Bukhara, Merv, Nishapur, Ray etc. There are still lists of works by Bulgar-Tatar scholars of the 10 th - 14th centuries in archives of Iran. For example, "Big Tiryak" by the Bulgar scientist of pre-Mongol period Taj al-Din al-Bulgari, found and published in the library of the Mejlis (Parliament) of Iran (Tadzhaddin al-Bulgari, 1997).

After the Mongol invasions Iran and the Volga region were part of the Mongol Empire. Despite the fact that at the end of the 19th century The Mongol Empire was divided into several independent "ulusi" ("udeli"), and the Volga region and Iran became a part of independent states (the Golden Horde and powers of Ilkhans-Hulaguids), it did not alleviate the cultural interaction between them. Arab, Persian and Tatar merchants and "shakirdy" who got their education in Muslim countries, brought in the Volga region monuments of Muslim (Arabic and Persian) 
science and literature, and other historical and cultural values.In madrasah of Sarai and Bulgar people from the Arab Middle East and Iran were trained. Tatars perceived Arabic as the language of the Koran, theology and science, and Farsi - the language of literature. Most of the extant literary works of writers of the Golden Horde ("KhusrauvaShirin" Qutb, "Mahabbat-name" Khwarizmi, "Gulistan bi-t-Turks" Saif Sarai et al.) are written under the influence of classical Persian literature. A large number of Persian epigraphic inscriptions found during the excavation of the Golden Horde cities, demonstrate the widespread of Persian language in daily use of educated local population.

In the late 14th-early 15th centuries, the territories of Central Asia, Iran and Afghanistan were united under the authority of the state, created by Emir Timur. After the death of Amir Timur, it disintegrated into several independent domains, some of which existed before the beginning of the 16th century. There were close diplomatic and trade relations between "Timurid" and Tatar states (the Golden Horde and Tatar khanates, formed after its dissolution). Cultural heritage of the "Timurid" era had a strong influence on medieval Tatar culture. In the first half of the 16th century, the Tatar states (the Khanate of Kazan, Astrakhan Khanate and the Nogai Horde) and Iran continued to develop trading, cultural and diplomatic relations.

In the 13-20th centuries literary Farsi was taught in all major Tatar madrasah. For instance, "Panda-name" ("The Book of edification") Farid al-Din Attar (c. 1119 - 1223) and "Bustan" ("Orchard") Muslim al-Din Saadi (between 1203 and 1210 - 1292) were used as textbooks. According to numerous written sources, "shakirdy" of Tatar madrasah who studied Farsi, its features and beauty of Persian poetry, memorized these texts, making interlinear translations of individual words in their manuscripts.It is not a mere coincidence that both verse and the content of works of Tatar poetry of the Middle Ages and modern times reveals the influence of classical Persian poetry. Tatar Sufi poetry developed in accordance with the traditions of Persian-Tajik poets.Here are some examples: Muhammedyar (1496/1497-1549), Kul-Sharif (died in 1552), Maule Kuly (1630 - early 18th century), GabdrahimUtyz-Imyani (1754-1834), Abulmanih Kargali (1782-after 1833), HibatullSalihov (1794-1867), Gabdeldzhabbar Kandali (1797-1860), Ali Choukri, Shamsuddin Zaki (1822-1865).

After Kazan (1552-1557) and Astrakhan (1554-1556) khanates became part of the Russian state, diplomatic and trading relations between Russia and Europe with Iran in the Volga region developed. Tatars played significant role in the trade relations between Russia and Iran. From 1620, Kazan was the geographical and socio-cultural border; the Asian merchants were allowed to reach it. In Russian archives we can find some information about the visits of Iranian merchants to Kazan.

The Russian government traditionally used the Tatars in their diplomatic and trade relations with the Muslim East and Iran as well.

In the second half of the 18th century - the middle of the 19th century, a system for training experts in oriental languages, translators and candidates for further training in the oriental departments of colleges and universities in secular secondary schools in Russia was formed.

Series of published and archival documents, which cover the events, the names, the process of the Persian language learning, the formation of scientific study of the history and culture of the peoples of Iran in Kazan in the 19th century are of a great interest (From the history of Kazan Iranian Studies, 2013).

First Kazan gymnasium and Oriental department of Kazan University played an important role in the oriental languages teacher training for educational institutions of the Empire. The study of the Persian language became the leading research area in both institutions.

In 1822 in the First Kazan gymnasium Arabic and Persian were taught by F.I. Erdman;in 1826 MirsaA.K.Kazem-Bek was Muslim Languages teacher; in 1833 K.Foygt was the Persian language teacher. In 1835, according to the Minister of Education S.S. Uvarov's report (1786-1855), Emperor Nicholas I approved the decree on the includingArabic, Persian, Tatar and Mongolian into the Kazan gymnasium's curriculum so that interpreters would be trained for the Empire's needs, etc (Kulikova, 1994).

In the first half of 19th century F. Erdmann, K. Voigt, N. Sonin (I. Bagirov), K. Popov, I. Ivanov were lecturers and trainees of the Persian language in the First Kazan gymnasium.

In 1836, the following educational and methodical programmes were issued in the Kazan gymnasium: "The distribution of teaching Arabic, Persian, Turkish and Tatar" by F.Erdman and "Distribution of teaching Arabic, Persian, Turkish and Tatar" by A.K. Kazem-Bek. 10 out of the 14 gymnasium students were learning Arabic, Persian, Turkish and Tatar. Other Muslim languages were taught as well. In general, the main aim was to train future experts of the Arab-Muslim East able to speak Arabic, Persian and Turkish.

In the beginning of the 40 's and 50 's of the 19th century the main teaching method was the integration of 
gymnasium and University culture and the Persian language courses and other Oriental languages as well. In March 1849 seven-year course of Oriental languages study in the school, including Persian, turned into a four-year one. In the second half of the 40's - early 50's in 19th century students studied the Persian language in the framework of the Arab-Persian and Persian-Armenian section of the Kazan gymnasium Oriental department.

In the early 50's of the 19th century the theoretical part of teaching the Persian language in the gymnasium included: "reading and writing" (IV class); "the detailed explanation of the etymology" and "easy translations with a detailed etymological analysis and explanation" (class V); "a brief systematic rendering of syntax" and "translation" (class VI); "reading" and "interpretation of difficult translation" (VII class) and etc. Teaching a language was to orient the students to: "reading printed works and manuscripts, written in different hands, with a special observation of the correct pronunciation" (IV-V classes); "making phrases with words memorized" or "interpretation" and "conversations" in Persian as well (V-VI grades); "learning by heart and recitation of selected poetic extracts; private letters and official papers common in the hostel writing" (VII class) and so on (Natsional'nyy arkhiv Respubliki Tatarstan. Fond. 977, Opis'. Istoriko-filologicheskiy fakul'tet. Delo. 652, Listy.26 - 29).

In the first half of the 19th century, the department of Oriental literature of the Kazan Imperial University became the center of Oriental studies in Russia and Europe and history and culture study of the peoples of the Iranian civilization. Further Iranian discipline and cultural history of Iran can be seen in the orientalists' researches of Kazan Universityand other educational and research centres. Following the original sources one can see the way educational and scientific field in Iranian historical-cultural and ethno-linguistic study developed in 19th century in Kazan.

The origin of Iranian studies in Kazan University goes to a scholar and Persian teacher Kh.D. Fren(1807-1817) and his student Y.O. Yartsev (1792-1861).

In 1807-1818 Kh.D. Fren initiated the study of Sasanian numismatic material, the decryption of early Arab-Muslim coins (Sassaniancoinage) and the Iranian monetary units (the History of Russian Oriental studies until the mid-19th century (1990, p. 213).

Y.O. Yartsev is associated with one of the first University scientific expeditions from Russia to Iran under Qajar rule. In 1817 - 1818, Y.O. Yartsev was a member of Russian Embassy in Persia (national archive of the Republic of Tatarstan (Natsional'nyy arkhiv Respubliki Tatarstan. Fond.92. Opis'. D.822).

On his arrival he presented at the University Council "Short diary of a journey to Persia", "Notes made during the journey from Tiflis to Astrakhan" and "Discourse on the religion of the Persians". Master Y.O. Yartsevwas awarded the Persian Shah badge of the order of Lion and Sun for success in learning the Persian language.

The main role in the scientific study of the history and culture of the peoples of Iran at the University until the mid -19th century played the chair of the Arab-Persian literature created in 1828. The head of the chair was F.I. Erdman (1793-1863) until 1845, in 1846-1849 it was A.K. Kazem-Beck. In 1849-1855it was headed by Professor I.F. Gotvald (Natsional'nyy arkhiv Respubliki Tatarstan. Fond.977. Opis'.619. Delo.36., Natsional'nyy arkhiv Respubliki Tatarstan. Fond.977. Opis'.619. Delo.37., Natsional'nyy arkhiv Respubliki Tatarstan. Fond.977. Opis'.619. Delo.43., Natsional'nyy arkhiv Respubliki Tatarstan. Fon.977. Opis'.619. Delo.44; Мазитова, (1972, c.21-149); David Schimmelpenninck van der Oye, (2010).

Professors-iranistsof the Oriental Philology department of the Kazan University were F.I. Erdman (1793-1863), Mirza A.K. Kazem-Beck (1802-1870), I.N. Berezin (1818-1896) and K.K. Foigt (1808-1873). They were the teachers of Persian language at the University, translators, textual critics, historians and commentators Iranian literary and historical works.

Along with the major professors in the department the Persian language and calligraphy lessons were given by lecturers, adjuncts and teachers like A. Mir-Mominov (1839-1845), M.G. Mahmudov(Oriental calligraphy, 1843-1855), Abdussatar Kazem-Bek (1849-1855, taught the Persian language and literature), I. Ivanov (1845-1850), N. Sonin (1846), I. Kholmogorov (Arabic and Persian languages, 1849-1852).

In the curriculum of the Arab-Persian study for the University students along with Arabic and Persian languages such Iranian discipline was included as "Political history of the Persian State", "History of Persian literature", "Asian numismatics", etc. Thus, special courses on the political history of Iran and the history of Persian literature were done at Kazan University.

According to the materials the professors of the department of Oriental literature reviewed Muslim languages textbooks. For example, in September 1842, Professor A. Kazem-Bek reviewed "Concise Grammar of the Persian language" (1841) by Abbas Kuli-Agha Bakikhanov (1794-1847). 
The Kazan iranists' publications testify to their great scientific interest in Persian manuscripts, Iranian languages, Persian culture and dialectology of Iran.

In 1822 F. I. by Erdman described Persian manuscript of Iskander Munshi. I. F. Erdmann is associated with the study of Rashid ad-Din's writings (1247-1318) and the study of Oriental historical sources of the Mongol period, Persian Chronicles as well. In "YchenyzapiskiKazanskogoUniversiteta"(Kazan University scientific articles)(1840) he examined the text "History of the Mongols in Iran" taken from the "Jami at-tavarikh" by Rashid ad-Din prepared by the French orientalist Etienne-Marie Katrmer (1782-1857) (Paris, 1836).

In 1840 F. I. Erdman published an article devoted to the analysis of materials of Herodotus about the ancient Persian history, where he critically evaluated the article written by Professor Derpt University K. L. Blum, published in 1836. F. I. Erdman pointed out that "the Persian writers works were not known to us for a long time, or at least were not used". According to the scholar, Herodotus borrowed his historical materials from written or oral Persian sources (Erdman, (1840, kn. 1, c. 92 - 94). F. I. Erdman studied numismatic material of the Muslim dynasties of Iran and the Turkic-Mongol states of Central Asia in Kazan as well.

In 1852, I.N. Berezin began to publish his translations "Jami at-tavarikh"by Rashid ad-Din. He chose the places that seemed to him the most valuable for Russian history.

The materials published or manuscriptson Iranian studies by the University professors S. I. Nazarians (1812-1879) and Mirza A.K. Kazem-Beck (1802-1870) especially, show the field of the study of Persian literature and the evidence of the origins of the domestic Iranian studies branch in Kazan in the first half of 19th century.

In 40's 19th century Kazan University adjunct S.Nazarians began studying the works of the classics of Persian poetry (Ferdowsi, Saadi) and drew attention to the urgent task of studying the Persian original of the Shah-Namie (Nazarian, 1849; Nazarian, 1849 - 1851; Nazarian, 1857).

In 1826-1849, at the Kazan University, the Arabic, Iranian, Turkic and Osman Study were presented at the teaching and scientific activities of Professor Mirza A.K. Kazem-Beck.

In 1848 in the journal "Severnoye Obosreniye" (Northern review) he published the original article "Mythology of the Persians according to Ferdowsi". His comparative analysis of Greek and Persian mythology is of a significant importance. Mirza A.K. Kazem-Beck's reflections on the genesis, nature, and images of Persian mythology are of a great interest.

In the Russian archives in Kazan and St. Petersburg manuscripts by MirzaKazem-Bek on "language and literature of the Persians before Islam", "Persian literature", "Iranian epic", "epic tales of the ancient Persians", "mythology of the Persians". are preserved. Professor Kazem-Bek's most noticeable achievement in the field of Iranian Studies was "Avesta" and the doctrine of Zoroastrianism. His enormous interest in European researches in the field of Avesta and the doctrine of Zoroastrianism is evident. According to Mirza Kazem-Bek, Zoroaster was a historical figure, thinker, and founder of the progressive creed.

Kazem-Bek'sintense interest in cuneiform texts and the languages of ancient Persian civilization, understanding of the stages of formation and development of Iranian languages and literatures, the study ofclassical Persian poetry, political, social and cultural life of 19th century Iran should be also mentioned(reforms, the press, babidi, socio-political institutions and etc).

Promising University tradition of Orientalism in Kazan in 19th century was the preparation and organization of scientific expeditions to Persia and the Middle East. The significant feature of Kazan School of Iranists was practical training of pupils with native Iranian speakers, direct acquaintance with the history, languages, culture, lifestyle and customs of the peoples living in Iran.

Kazan University students I. Beresin and V. Dittel's (1816-1848) scientific expedition to the Middle East (1842-1845) had a significant importance in the history of Russian and European Arabic, Iranian, Osman and Caucasian studies. While travelling around the main centres of Persia, Iraq, Syria, Palestine, Egypt and Turkey, I. Beresin and V. Dittel improved their Persian, Arabic, Turkish and learnt various geography, topography, ethnography, history and culture of Southeast Asia as well. (Natsional'nyy arkhiv Respubliki Tatarstan. Fond.977. Opis'. Rektor. Delo.654.; Natsional'nyy arkhiv Respubliki Tatarstan. Fond.977. Opis'. Rektor. Delo.837; Natsional'nyy arkhiv Respubliki Tatarstan. Fond.977. Opis'. Sovet. Delo.2450; Rossiyskiy gosudarstvennyy istoricheskiy arkhiv. Fond.733. Opis'.42. Delo.306).

In 1850-1852 I.N. Beresin published two volumes of "Journey to the East", which gives an original literary, scientific and popular description of Dagestan, South Caucasus and Northern Persia. In addition to it, in the 40's 
and 50's 19th century I.N. Beresin published a variety of travel essays devoted to the languages, history, customs, traditions, archaeology and monuments of Turkic, Iranian and Arabic peoples of the South Asia.

In 1851-1852 the Iranist I.N. Beresin published an article in French dedicated to the study of the dialects of the Persian language (Recherchessur les dialectespersans, par E. Beresine, (1851, kn.2, c. 67 - 224), (1852, kn. 2, c.1 - 149), (1852, kn. 3, c. 43 - 119). His "Grammar of the Persian language" (Grammar of the Persian language, compiled by I.N. Beresini, Professor KU, (1853)) plays a significant role in the study of Iranian linguistics in Russia and Europe. Original linguistic material was collected during his travels and visits to major centres of Persia in 1844: Tabriz, Tehran, Isfahan, Istakhr, Shiraz, Kazerun, Bandar Bushire.

The official translations of the Persian shahs' letters were published in 19th century in Kazan. This is evidenced by the publication of Russian texts firmans "Nadir Shah to his son Reza-Cooley-Mirza concerning Indian expeditions", written in 1738 (Nadir Shah to his son Reza-Cooley-Mirza concerning Indian expeditions (1870, v.6, p.313-320).

Official project of centralization of Oriental studies in St. Petersburg and its implementation on the basis of the faculty of Oriental languages of the University in 1854/1855 had a negative effect on further teaching of the Persian language and other Oriental languages in gymnasium and the University of Kazan.It also had a negative effect on the official teaching of the Iranian languages in the schools and colleges of Russia in the second half of 19 th - early 20th centuries.

In the second half of 19th - early 20th centuries the revival of Iranian and Oriental studies in Kazan was associated with the organization and teaching of Muslim languages at Kazan University, with the activities of the Oriental societies - Eastern society (1855), the Society of archeology, history and Ethnography at the Kazan State University (1878-1829,) and new Oriental education institutions and associations that emerged at the stage of formation of the Soviet Oriental studies (1917-1920-s).

In the 60's-early 70-ies of 19th century I.N. Kholmogorov (1818 -1891) taught Arabic and Persian languages at the Kazan University, read lectures: "History of the Arabians" and "History of the Persian State from the conquest of Persia by the Arabs and the introduction of Islam to the present era." In 1860 Professor I.N. Kholmogorov published a translation of "History of sarbedaran" taken from the fifth volume of the history of Mirkhond"The Rauzat-us-Safa"(Garden of Purity). One of the reasons for textual analysis of the text he considered the fact that it had not been translated into a European language before (Kholmogorov, (1860, Vol. 4). This list of manuscripts "The Rauzat-us-Safa" belonged to the Persian Consul in Astrakhan Mirza Yusuf Khan.

In 1867-1868 I.N. Kholmogorov had a following new scientific expedition to Persia, which had the same significance asthe ones made by Russian and European scientists in the countries of the Arab East of 19th beginning 20th centuries.

Published materials and documents kept in Russian archives show that the Iranian discipline occupied an important place in the projects of the "Asian Institute at the Imperial Kazan University" (1843), the Eastern branch of the historical-philological faculty of Kazan University $(1905,1916-1919$,$) and Oriental languages$ courses (1911-1912). Persian language, Persian literature, history and culture of the peoples of Persia were realised in Kazan through the activities of the North-East archaeological and ethnographic Institute (1917-1921), later converted to Oriental Academy (1921-1922).

A short period of life and work of the iranist B.V. Miller (1877-1956) in Kazan should be studied as it is almost neglected. He used to teach new Persian, Persian literature and history of Iran in new Oriental education institutions.

\section{Discussions}

At the present stage historical and scientific study of the richest Persian history and culture in the history of Russian and European Iranian Studies and Oriental Studies is still perspective, as well as the phenomenon of political and cultural ties between the peoples of Russia - Iran - West. Rich archival materials and funds of Russia, Azerbaijan, Ukraine, Kazakhstan, Turkmenistan, Uzbekistan and the countries of Europe are of particular research interest, devoted to Iranian studies and Persian historical and cultural heritage.

\section{Conclusion}

The basic field of University Orientalists was teaching the Persian language, linguistic, literary, historical, ethnographic research, dedicated to the peoples of Iran. Numismatic material of the Muslim dynasties of Iran and the Turkic-Mongol state in Central Asia were studied here. An important field in Iranian studies in 19th century Kazan was the study of the works of Persian-Tajik classical literature. Scientific and educational traditions of the 
study of Iranian civilization in Kazan in 19th -20th centuries show the following main fields and their features: the teaching of the Persian language based on classical literature and epics; research in the field of live Persian speech, folk art, folklore and dialects of the peoples of Iran; preparation and publication of academic programs, textbooks, handbooks, dictionaries, study of Persian manuscripts and books of monuments of Iranian culture and civilization; translations of Persian authors and publication of original philological, historical, cultural, natural-geographical, archaeological and ethnographic papers and works on the history and culture of Iran.

Nowadays complex historical and scientific analysis of the rich Persian history and culture in the history of Russian and European Iranian studies and Oriental studies, as well as the phenomenon of political and cultural relations of the peoples of Russia - Iran - West is still actual.

The authors express their gratitude to the Russian state scientific Fund and the editorial Board of Asian social science journal for support in the preparation and implementation of this project.

\section{Acknowledgments}

The work is performed according to the Russian Government Program of Competitive Growth of Kazan Federal University

\section{References}

Andreeva, E. (2007). Russia and Iran in the Great Game: Travelogues and Orientalism. New York.

Erdman, F. (1840). Irodot zaimstvoval povestvovanie o drevnepersidskoy istorii iz persidskikh istochnikov. Uchenye zapiski Kazanskogo universiteta, 1, 92-94.

Grammatika persidskogo yazyka, sostavlennaya I. N. Berezinym, prof. KU. (1853). Kazan'.

Gramoty Nadir-shakha svoemu synu Ridza-Kuli-Mirze, kasayushchiesya indiyskikh pokhodov Nadira. (1870). Uchenye zapiski Kazanskogo universiteta, 6, 313-320.

Hodkinson, J., Walker, J., Mazumdar, Sh., \& Feichtinger, J. (2013). Deploying Orientalism in Culture and History: From Germany to Central and Eastern Europe. Camden House.

Istoriya otechestvennogo vostokovedeniya do serediny XIX veka. (1990). Moskva, 213.

Istoriya otechestvennogo vostokovedeniya s serediny XIX veka do 1917 g. (1997). Moskva.

Iz istorii kazanskoy iranistiki: Sbornik dokumentov. (2013). Kazan.

Kholmogorov, I. (1860). Istoriya Serbedarov (iz V toma obshchey istorii Mirkhonda «Rauzatussafa»). Uchenye zapiski Kazanskogo universiteta, 4.

Kulikova, A. M. (1994). Vostokovedenie v rossiyskikh zakonodatel'nykh aktakh (konets XVII v. - 1917 g.). Sankt-Peterburg.

Mazitova, N. A. (1972). Izuchenie Blizhnego i Srednego Vostoka v Kazanskom universitete (Pervaya polovina XIX veka). Kazan': 21-149.

Natsional'nyy arkhiv Respubliki Tatarstan. Fon.977. Opis'.619. Delo.44.

Natsional'nyy arkhiv Respubliki Tatarstan. Fond. 977, Opis'. Istoriko-filologicheskiy fakul'tet. Delo. 652, Listy. 26-29.

Natsional'nyy arkhiv Respubliki Tatarstan. Fond.92. Opis'. D.822.

Natsional'nyy arkhiv Respubliki Tatarstan. Fond.977. Opis'. Rektor. Delo.654.

Natsional'nyy arkhiv Respubliki Tatarstan. Fond.977. Opis'. Rektor. Delo.837.

Natsional'nyy arkhiv Respubliki Tatarstan. Fond.977. Opis'. Sovet. Delo.2450.

Natsional'nyy arkhiv Respubliki Tatarstan. Fond.977. Opis'.619. Delo.36.

Natsional'nyy arkhiv Respubliki Tatarstan. Fond.977. Opis'.619. Delo.37.

Natsional'nyy arkhiv Respubliki Tatarstan. Fond.977. Opis'.619. Delo.43.

Nazariants, S. (1849). Abul' Kasem Ferdausi Tusskiy, tvorets knigi tsarey, izvestnoy pod nazvaniem Shakh-name, s pribavleniem beglogo obzora istorii persidskoy poezii do iskhoda KhU stoletiya po R.Kh. Uchenye zapiski Kazanskogo universiteta, 3: 136.

Nazariants, S. (1849-1851). Abul-Kasem Ferdausi Tusskiy, tvorets knigi tsarey, izvestnoy pod nazvaniem Shakh-name. S prisovokupleniem kratkogo obzora istorii persidskoy poezii do iskhoda XV stoletiya po 
R.Kh. Kazan', 1-2.

Nazariants, S. (1857). Rozovyy kustarnik Sheykha Muslekheddina Saadi Shirazskogo, slavnyy pod nazvaniem Gulistan. Moskva.

Recherches sur les dialectes persans, par E. Beresine. $(1851,1852)$. Uchenye zapiski Kazanskogo universiteta, 2, $67-224 ; 2,1-149 ; 3,43-119$.

Rossiyskiy gosudarstvennyy istoricheskiy arkhiv. Fond.733. Opis'.42. Delo.306.

Schimmelpenninck van der Oye, David. (2010). Russian Orientalism. Asia in the Russian Mind from Peter the Great to the Emigration. Yale University Press. http://dx.doi.org/10.12987/yale/9780300110630.001.0001

Tadzhaddin al-Bulgari. (1997). Bol'shoy Tiryak (Bol'shoe protivoyadie) / Izd. teksta, perev. s arabskogo, predisl., kommentariy A. B. Khalidova. Kazan.

Valeev, R. M. (1998). Kazanskoe vostokovedenie: istoki i razvitie (KhIKh v. - 20-e gg. XX v.). Kazan'.

\section{Copyrights}

Copyright for this article is retained by the author(s), with first publication rights granted to the journal.

This is an open-access article distributed under the terms and conditions of the Creative Commons Attribution license (http://creativecommons.org/licenses/by/3.0/). 